\title{
LYING AND THE FIRST AMENDMENT
}

\author{
Thomas Halper*
}

\begin{abstract}
The first amendment does not protect all speech. Should it protect lies? Some argue that the state should intervene to prevent and punish lying because the people are insufficiently rational (they are too emotional, and, therefore vulnerable) or excessively rational (they find it too costly to investigate claims and are, therefore, vulnerable). Others retort that state officials are not neutral or objective, but have their own interests to advance and protect, and, therefore, cannot be trusted. Though certain kinds of lying, like fraud and perjury, are clearly not protected speech, courts have recently seemed sympathetic to the view that the proper response to lying is not government action, but the workings of the marketplace of ideas. The distinguished economist, Ronald Coase, has taken this argument much farther, applying it to commercial speech, but thus far his views have not prevailed.
\end{abstract}

First Amendment, Lying, Supreme Court

\section{KEYWORDS}

\section{CONTENTS}

I. LYING AND the FiRST AmENDMENT .................................................. 402

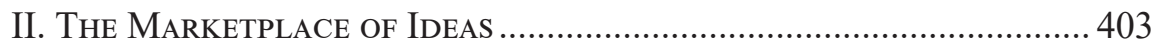

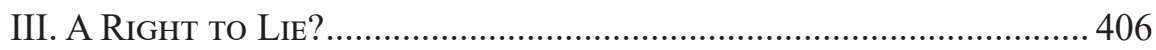

IV. United States v. Alvarez............................................................ 411

V. Susan B. Anthony List v. Driehaus ........................................... 413

VI. National Institute of Family and Life Advocates v. Becerra .. 415

VII. Ronald H. Coase, “Advertising and Free Speech” .................. 421

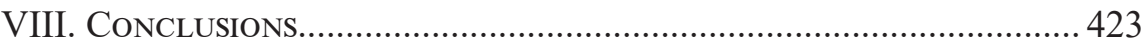

* Baruch College/City University of New York Graduate Center.

E-mail: Thomas.Halper@baruch.cuny.edu 


\section{LYING AND THE FIRST AMENDMENT}

The first amendment to the United States' Constitution may sweepingly proclaim that "Congress shall make no law . . . abridging the freedom of speech, or of the press," but it has never been read by the Supreme Court to ban all restrictions on all speech, and the argument has been made, pointing at perjury, ${ }^{2}$ fraud, ${ }^{3}$ and false advertising ${ }^{4}$ that it does not protect lying. Lies, that is deliberate falsehoods spoken with the purpose to deceive, are said to be inherently bad (morally disrespectful to the listener and dehumanizing to the liar), as well as bad in their consequences (poisonous to discourse and human relationships). ${ }^{5}$ Almost no one defends lying as a good thing. Thus, even when the Supreme Court all but obliterated a public official's chances of winning a libel suit, it was careful to exclude assertions made with "a knowledge that they were false" from protection.

And yet courts, wary both of encouraging self censorship and of approving content based restrictions, have sometimes been reluctant to exclude lies from constitutional protection. A complicating factor is that lies, especially effective lies, are often mixed with truths; indeed, it is the element of truth that may render the lie credible. This paper will explore the issue of lying and the first amendment in the context of national and state statutes plus an argument presented by Ronald Coase, a Nobel Laureate in economics. ${ }^{7}$

There is nothing new about lying, as the serpent's tale to Eve about the consequences of sampling fruit from the tree of knowledge of good and evil well illustrates. ${ }^{8}$ But today the topic blooms like a ravenous noxious weed, with the Oxford Dictionary naming the 2016 word of the year "post-truth," and "alternative facts" 10 and "fake news" 11 becoming les sujets du jour. The most bizarre allegations, for example, linking Hillary Clinton to a pedophile ring operating out of a pizza parlor, strike millions of citizens as perfectly plausible, ${ }^{12}$ and European officials complain that state sponsored fake news is generated at such a torrential pace that

U.S. Const., amend. I.
E.g., 18 U.S.C.A. § 1621 .
E.g., 18 U.S.C.A. § 341.
E.g., 15 U.S.C.A. § 1125.

Lying may also take the form of generating doubt where none is justified. The tobacco industry, for instance, "defended its primary product - tobacco - by manufacturing something else: doubt about its harm." NAOMI ORESKES \& ERIK M. CONWAY, MERCHANTS of DoubT 34 (2010).

$6 \quad$ N.Y. Times v. Sullivan, 376 U.S. 254, 279 (1964).

7 This paper addresses only lying. It does not address falsehoods honestly made, misleading truths, or mere opinions, which resist true/false designations.

8 Genesis 3:4.

9 Amy B. Wang, "Post-Truth" Named 2016 Word of the Year by Oxford Dictionaries, Wash. Post, Nov. 16, 2016.

10 Eric Bradner, Conway: Trump White House Offered "Alternative Facts" on Crowd Size, CNN.com, Jan. 232017.

11 Angie Drobnic Holan, 2016 Lie of the Year: Fake News, PolitiFact.com, Dec. 13, 2016.

12 Public Policy Polling.com, Dec. 9, 2016. Fourteen percent of Trump supporters believed the accusation, and thirty-two percent were not sure. 
it quite overwhelms any efforts to counter it. ${ }^{13}$ A Time magazine cover asked, "Is Truth Dead?"14 And that governments and politicians lie are likely truths as ancient as governments and politicians themselves. ${ }^{15}$

United States v. Alvarez (2012) concerned a minor official who falsely claimed at a public meeting that he had been awarded the Congressional Medal of Honor, the nation's highest medal for combat bravery, in violation of a national law that made such lies criminal offenses. Susan B. Anthony List v. Driehaus (2016) dealt with a suit brought under state law banning campaign lies. National Institute of Family and Life Advocates v. Becerra addressed a state law compelling speech as a cure for deceptive silence. "Advertising and Free Speech" by Ronald H. Coase maintains that commercial speech should be treated constitutionally like any other speech and enjoy the full protection of the first amendment, including whatever protection is granted to lying. The material I discuss will illustrate how a contemporary society, "post-truth" and awash in fake news, addresses the problem.

\section{THE MARKETPLACE OF IDEAS}

Perhaps the most common rationale for freedom of speech in the aggressively individualistic United States is the marketplace. As Milton famously wrote in Areopagitica (long before there was a United States), "Let [truth] and falsehood grapple; who ever knew truth put the worse in a free and open encounter?"16 The view that truth will win in the end, however, is open to serious and numerous reservations. How are we to know that what we believe is true is actually the truth that has won out? Perhaps it is a falsehood that has triumphed, for we naturally always think that whatever we believe is true, even if it is not. Also, since, as Keynes observed, "In the long run, we are all dead," by the promise of eventual victory? Before it was accepted that the earth revolves around the sun, dozens of generations lived and died, confident in believing the opposite. Also, Milton posits "free and open" encounters, but how common are they, given the advantages typically enjoyed by the status quo? Do we really choose beliefs in the marketplace of ideas in the same way we choose, say, deodorant or beer, in the marketplace of products? For we overvalue our pre-existing beliefs as a way of saving us from having to admit mistakes; we perceive (or misperceive) information to reinforce these beliefs; we are reluctant to view events from another person's perspective; we tend to prefer things the way they are over an uncertain,

13 Mark Scott \& Melissa Eddy, Europe Combats New Enemy of Political Unity: Fake News, N.Y. Times, Feb. 21, 2017.

14 TIME, April 3, 2017. A half century earlier during the Vietnam War, pundits complained of a "credibility gap." Josh Zeitz, How Americans Lost Faith in Government, WaSH. Post, Jan. 30, 2018.

15 The insistent call for social media to police their content by banning sites that lie raises many of the problems inherent in government's performing the same function. Indeed, the absence of electoral accountability might render the social media's position even weaker.

16 John Milton, Areopagitica 58 (Richard C. Jebb, ed. Cambridge Univ. Press, 1918) (1644).

17 J.M. Keynes, A Tract on Monetary Reform 80 (Macmillan, 1924). 
different form they might take in the future; we are generally more worried about potential losses than cheered by potential gains; and we may well be governed by socialization that inculcates beliefs at an early age, leaving us content to search for information that merely confirms what we learned years before we were able to think for ourselves. Lies, as Hannah Arendt observed, "are often much more plausible, more appealing to reason, than reality, since the liar has the great advantage of knowing beforehand what the audience wishes or expects to hear. He has prepared his story for public consumption with a careful eye to making it credible, whereas reality has the disconcerting habit of confronting us with the unexpected for which we were not prepared." 18 Our innate psychological tendencies, in short, leave us open to manipulation by those seeking to use them for their own purposes. Indeed, efforts to counter misinformation may actually do more harm than good. ${ }^{19}$

Technology, moreover, has seriously amplified the problem. Deep fakes, involving impersonation by digital manipulation, are making it possible to present people saying and doing things they never did - and the typical audience is entirely unaware of the deception. ${ }^{20}$ The potential for reputational damage, blackmail, electoral abuse, national security errors, and undermining public and interpersonal trust is so enormous that it seems fatuous to offer the marketplace as a corrective. The bromide that seeing is believing turns out to be an invitation to be conned.

All of which suggests that correction cannot reliably be purchased simply by providing more and better information. ${ }^{21}$ In fact, the standard method of presenting both sides of an issue is apt to strengthen attachment to prevailing views ${ }^{22}$ and even retracting a false assertion may by repeating it harden the belief. ${ }^{23}$ That we

18 Hannah Arendt, Lying in Politics: Reflections on the Pentagon Papers, N.Y. Rev. OF BKs., Nov. 18, 1971.

19 Edward Glaeser \& Cass Sunstein, Does More Speech Correct Falsehoods? 43 J. Leg. STUD. 65, 73-90 (2014).

20 Robert Chesney \& Danielle Citron, Deep Fakes: A Looming Crisis for National Security, Democracy and Privacy? (2018) available at https://papers.ssrn.com/sol3/ papers.cfm?abstract_id $=3213954$. The authors suggest that firms may arise to provide protection by tracking our acts, but concede that this would threaten privacy, grant the firms tremendous power, and tempt government to use the data for its own purposes. Another commentator speaks of tort suits using defamation or right of publicity, but these remedies might not be widely available and, in any case, could be activated only after the lies had been spread. Jesse Lempel, Combatting Deep Fakes through the Right of Publicity, Lawfare, Mar. 30, 2018. Other commentators, regarding fake news as political advertising, argue that the answer is greater transparency in the form of mandated disclosures, but in addition to obvious enforcement problems, it appears doubtful that the disclosures would prove effective. Abby K. Wood, Ann M. Ravel \& Irina Dykhne, Fool Me Once: Regulating "Fake News" and Other Online Advertising, 91 So. CaL. L. Rev. 6 (2018).

21 BrendanNyHan \& JasonReifler, WhenCoRRECTIONSFAIL:ThePERSISTENCEOFPOLITICAL Misperceptions, 32 Pol. Behav. 303, 304 (2010).

22 Charles S. Taber \& Milton Lodge, Motivated Skepticism in the Evaluation of Political Beliefs, 50 Am. J. Pol. ScI. 755 (2006).

23 B. Swire, U.K.H. Ecker \& S. Lewandowsky, The Role of Familiarity in Correcting Inaccurate Information, 43 J. of Experimental Psych.: Learning, Memory, and Cognition 1948 (2017). 
are normally quite unaware of these biases indicates that it will never occur to us to challenge them. ${ }^{24}$ No wonder a study of 126,000 stories tweeted by more than three million people more than 4.5 million times concluded that falsehoods spread faster and reached more people than truths. ${ }^{25}$

But if the marketplace rationale is radically imperfect, still the standard American view is Holmes' classic statement: "the best test of truth is the power of the thought to get itself accepted in the competition of the market." ${ }^{26}$ Not the perfect or infallible test, for elsewhere he admitted that the "beliefs expressed in proletarian dictatorship" ${ }^{27}$ may win out, certainly beliefs he personally abhorred. Instead, he avers that the marketplace, mindless and purposeless, was merely the best test available. And it is taken to be the best test because Americans, long suspicious of state power, are wary of officials making the determination of truth for them. We understand, as Weber said, that the state "claims the monopoly of the legitimate use of physical force," ${ }^{28}$ and we understand that the state is neither neutral nor benevolent, but is guided by persons with their own interests and beliefs to advance and protect. This may not always be obvious. In the West, leaders do not gain power like Machiavelli's Prince, violently eliminating his rivals, and in governing, our leaders are typically sensitive to the nooks and crannies of public opinion, flattering the people like a lothario in a silent movie. But in imposing their will, via the bureaucracy, the police, or the military, leaders (to switch the metaphor) urge the hidden wolf from its lair, and force is exposed.

Yet it may be unrealistic to assume that ordinary people have the knowledge, experience, or skills required to make these truth determinations, for acquiring all these resources is costly in terms of time, effort, lost opportunities, and money. We do not know what pharmaceuticals are safe and effective and so we rely on the Food and Drug Administration to tell us what they believe is the truth. Thus, in effect we deputize others, in government and out, to act as investigative truth squads on our behalf. Formerly, this might have meant heavy reliance on conventional print media. Today, it would include all kinds of social media, which may operate quite outside traditional journalistic norms and practices and direct their messages toward narrow, niche audiences seeking only reinforcement of preexisting views. The results, sad to say, are not always encouraging: thirty-six percent of Americans believe Obama was definitely or probably born in Kenya, and forty-two percent definitely or probably believe a handful of Wall Street bankers secretly planned the 2008 financial crash. ${ }^{29}$ To some, the proliferation of misinformation suggests a greater need for the state to intervene on behalf of the people. To others, the intervention of the state would merely supplant a present evil with a worse one. Meanwhile, pundits ruminate darkly about the metastatic proliferation of falsehoods, while postmodernists seem uncertain that truth is even a useful concept.

\footnotetext{
$24 \quad$ William Samuelson \& Richard Zeckhauser, Status Quo Bias in Decision Making, $1 \mathrm{~J}$. RISK \& UNCERTAINTY 7, 9 (1988).

25 Soroush Vosoughi, Deb Roy \& Sinan Aral, The Spread of True and False News Online, 359 SCIENCE 1146 (2018).

26 Abrams v. United States, 250 U.S. 616, 624, 630 (1919).

27 Gitlow v. New York, 268 U.S. 652, 672, 673 (1925).

28 Max Weber, Politics as a Vocation, in From Max Weber, 78 (H.H. Gerth \& C. Wright Mills eds. \& trans. N.Y.: Oxford Univ. Press, 1946).

29 Economist/YouGov Poll, Dec. 17-20, 2016.
} 
The first amendment, it would seem, is silent on the subject. It instructs Congress (and by extension via the fourteenth amendment, all levels of government ${ }^{30}$ ) not to abridge the freedom of speech, but does not pause to indicate what this vague term "freedom of speech" means. It is obvious that it cannot simply mean "speech," because if it did, the words "freedom of" would be superfluous. But if "freedom of speech" does not equal "speech," what does it mean? One answer is that freedom of speech is broader than literal speech, in the sense of covering such nonverbal expression as wearing a black armband to signify opposition to a war ${ }^{31}$ or raising a red flag to signal solidarity with a political movement. ${ }^{32}$ At the same time, freedom of speech is also narrower, as it does not include libel, obscenity, true threats, or fighting words. Consider the iconic legal venue, the courtroom trial, which is enmeshed in detailed restrictions as to whom may speak, what they may speak, even the order in which they are allowed to speak, and thus is far removed from any ideal, free wheeling marketplace that Holmes might have imagined. The contours of freedom of speech are hardly self evident.

\section{A Right to LiE?}

It is not surprising, then, that the question as to whether the first amendment protects the right to lie offers only complex and vexing answers. This is especially true, when lies are not of a personal nature, but instead concern information about which the audience has no direct knowledge; it will be easier to deceive me with information about a war in another continent than with a slur against my family. Of course, it would be absurd for a witness in a trial to lie, and then justify it by claiming freedom of speech. ${ }^{33}$ And it would be absurd to expect the protection of the first amendment for a salesperson to tout an off-label use of a drug through false marketing ${ }^{34}$ or for a patron falsely to shout fire in a crowded theatre and cause a panic ${ }^{35}$ or for a driver stopped for a violation to misrepresent himself as a policeman. ${ }^{36}$ Are systematic lies - for example, the traditional practice of doctors keeping bad news from patients "for their own good" - worse than individualistic lies - I tell my wife I was working late at the office, when I was actually engaged in a liaison with a mistress? It depends on the circumstances.

More than this, if we conceive speech as a principal means of connecting with other persons, combatting isolation and loneliness, sharing information and ideas, and cooperating for common purposes, lying emerges as a toxic corruptor, undermining trust and driving persons apart. For the purpose of lying is deception. Or to put it differently, the essence of lying is not falsity but belief and intention: If I say something I believe is false and present it as true I am lying, even if it develops that I was mistaken and inadvertently spoke the truth, so long as my purpose was to deceive. In this sense, lying entails treating the audience as unworthy to hear

\footnotetext{
Supra note 27.

Tinker v. Des Moines Independent Community School District, 393 U.S. 503 (1969).

Stromberg v. California, 283 U.S. 359 (1931).

Gates v. Dallas, 729 F. 2d 343 (1984).

United States ex rel. Polansky v. Pfizer, Inc., 822 F.3d 613 (2d Cir. 2016).

Schenck v. United States, 249 U.S. 47, 52 (1919).

United States v. Chappell, 691 U.S. F.3d 388 ( $4^{\text {th }}$ Cir. 2012).
} 
the truth, in short, with moral disrespect. Kant thought lying was always wrong because it denies the moral worth of the liar, who "annihilates his dignity as a human being, ${ }^{37}$ and impedes the rationality of the audience; both are used only as means, and not as ends. When you deceive me and deny me the opportunity to make a free rational choice, I become merely a means to some end you have selected, and the end itself is robbed of its goodness because it was not rationally pursued.

From a societal perspective, too, lying may contaminate the discussions that drive democratic accountability. If, for example, you believe that definitely or probably the $9 / 11$ attacks were planned by the United States - as a quarter of Americans $\mathrm{do}^{38}$ - then accountability means something quite different from believing that Al-Qaeda was to blame. Imagine, for example, a world in which lying was the default position. No statement could be trusted; every assertion would require personal verification, which in the aggregate would become so expensive no one could afford to perform it; handing down information from one generation to the next would be impossible, and so there could be no accumulation of knowledge and no material progress. With a cynical gullibility, the public would either believe nothing or, as Arendt put it, believe anything, "no matter how absurd, and [would] not particularly object to being deceived because it held every statement to be a lie anyhow." 39

Borges makes a related point in his story, "Tlön, Uqbar, and Orbis Tertius," where a secret society produces multivolume tomes on imaginary alien places; these fantasies gradually displace reality in the minds of the people, as they study and discuss the fantasies; in the end, "The world will be Tlön." ${ }^{40}$ Similarly, Dick wrote of implanting memories, so that the protagonist, having learned that the "extrafactual" are convincing, concedes that the "actual memory is second best." ${ }^{\prime \prime 1}$ In a variation on Gresham's law, lies drive out the truth. And, of course, 1984 featured a memory hole, where documents describing the past were incinerated, and replaced by the party's newer version of history, in which the party is always right. ${ }^{42}$ No wonder Kant believed that a lie "harms ... humanity generally," for "it vitiates the source of justice." ${ }^{\prime 3}$

On the other hand, if truth telling is the default position, the pervasive distrust and susceptibility to fantasy that hinder progress and accountability are removed,

37 Immanuel Kant, The Metaphysics of Morals ( Mary J. Gregor trans.) in Practical Philosophy 552-53 (Mary J. Gregor \& Allen W. Wood trans. \& eds. Cambridge: Cambridge Univ. Press, 1996) (1797).

38 Supra note 29.

39 Hannah Arendt, The Origins of Totalitarianism 382 (1951).

40 Jorge Luis Borges, Labyrinths: Selected Stories And Other Writings 43 (DonaldA. Yates \& James E. Irby eds., (1970/1940).

41 Philip K. Dick, We Can Remember It for You Wholesale, 30 FantasY AND SCIENCE Fiction 4 (April, 1966). Bertrand Russell famously observed, "It is not logically necessary to the existence of a memory-belief that the event remembered should have occurred or even that the past should have existed at all. There is no logical impossibility in the hypothesis that the world sprang into being five minutes ago, exactly as it then was, with a population that 'remembered' a wholly unreal past." The ANALYsis OF Mind 159 (1921).

42 George Orwell, 1984 (Boston: Houghton Mifflin, 1949).

43 Immanuel Kant, Critique of Practical Reason 433 (Thomas Kingsmill Abbott trans., London: Longman's, Green \& Co., 1879). 
and if you recognize that you benefit from veracity, you may decide that fairness requires that you reciprocate and foreswear lying yourself. ${ }^{44}$

Lying may also be conceived as an abuse of power. If I lie to you, I may be exploiting your need for me; you rely upon me for information, and I repay the reliance with deliberate falsehoods. It may also be a way of showing my disdain for you; a lie of sufficient brazenness implies that the audience is either too stupid to see the lie or too weak or passive to do anything about it. Such lies may entail contempt not only for the audience, but for truth itself, which like an obnoxious relative at a party, is best dealt with by ignoring that it is there. Or I may compel my subordinates to lie, undermining their relationships with others and leaving them more dependent upon me. By forcing them to lie, I test their loyalty to me, exposing them to possible embarrassment and humiliation; lying, in this context, becomes a kind of ritualistic humbling that undercuts the liar's self esteem and sense of personal worth. The ways in which lying is bad, in practice and in principle, are both numerous and well known. It is an easy step from all this to the conclusion that "there is no constitutional value in false statements of fact" ${ }^{45}$ or that "neither lies nor false communications serve the ends of the First Amendment." 46

But this is not the end of the story. If the Bible instructs, "Thou shalt not lie to one another," ${ }^{47}$ it also tells us to "[b]e kind and compassionate to one another," ${ }^{48}$ and it is obvious that these obligations may sometimes conflict, perhaps generating anxiety ${ }^{49}$ or the avoidance of the stressful conversation. ${ }^{50}$ Honesty, after all, may risk social rejection, a potent deterrent, or create embarrassment. In Genesis, for example, angels tells Abraham, aged ninety-nine, that his wife, Sarah, aged eightyeight and long post-menopausal, will become pregnant and have his son; Sarah overheard the prediction and laughs, saying, "Now that I am withered, am I to have enjoyment with my husband so old?" But to spare his feelings and keep peace in the home, God quotes her as saying, "Shall I in truth bear a child, old as I am?" omitting her reference to Abraham's presumed impotence. ${ }^{51}$ Thus, we may avoid painful honesty not only because it seems inherently wrong, but also because it may bring hurtful consequences in its wake. Elsewhere, Samuel, fearful that King Saul will kill him if he learns he is traveling to select a king to replace him, asks God for advice; the answer is to claim that he is merely bringing a heifer to sacrifice, in other words, to lie. ${ }^{52}$ Further evidence of God's willingness to countenance lies may be found in nature, where deception is ubiquitous, for example, in a possum's playing dead to foil a predator.

For nearly everyone acknowledges that lying is permissible under certain circumstances, for instance, when a murderer asks where a potential victim

\footnotetext{
Cf., Sissela BoK, Lying: Moral Choice in Private and Public Life (1978).

Gertz v. Robert Welch, Inc., 418 U.S. 322, 339-40 (1974).

St. Amant v. Thompson, 390 U.S. 727, 732 (1968).

Leviticus 19:11.

8 Ephesians 4:32.

49 Andrew L. Molinsky \& Joshua D. Margolis, Necessary Evils and Interpersonal Sensitivity in Organizations, 30 Acad. of Mgemt. Rev. 245 (2005).

50 Sidney Rosen \& Abraham Tesser, On Reluctance to Communicate Undesirable Information: The MUM Effect, 33 SOCIOMETRY 253 (1970).

51 Genesis 18: 9-15.

52 I Samuel 16:2.
} 
is hiding. ${ }^{53}$ Here, a life is at stake and the rarity of the situation indicates that it will have little precedential impact. Lying may also seem to be justified if it "is designed to benefit the person deceived," 54 as when a dentist persuades an elderly demented woman to wear her dentures by telling her "that I was marrying her son, and she needed to put that partial in before she could go to the synagogue" 55 or when you respond to an unwanted dinner invitation with, "Oh, I'm so sorry, I have plans with my family"56 or when you assure someone in great pain that everything will be alright. There is an element of paternalism here that some will find objectionable, but probably most people will conclude that in these situations, lying does not undermine relationships but in its consequences instead helps to sustain them. Lying may also be an accepted response to bigotry. For instance, a divorced Afghan woman admitted that she had to tell her landlord that her husband was away because he would not rent to a divorcee..$^{57}$ For truth is seen as trumped by the need to preserve a life, avoid hurt feelings, offer a dollop of hope that will make suffering bearable, or lease a place to live. Lying, which in the abstract may seem inherently wrong, may sometimes produce better consequences than truth.

Can lying be harmful? Of course. But other speech that is deliberately harmful, like hate speech, is protected by the first amendment, and so the corrosive harm of lies, by itself, the argument goes, should not disqualify them from coverage. Mill, who dismissed the marketplace defense as "one of those pleasant falsehoods," 58 argued that errors should not be suppressed -- presumably, this would also apply to lies -- because examining them gives people a "clearer perception and livelier impression of truth, produced by its collision with error," ${ }^{59}$ thus aiding in the development of a critical, inquiring mind.

Lies, or at least "investigative deceptions," ${ }^{60}$ also, paradoxically, may be a means to truth, as when journalists lie to sources in order to induce them to say what they know. Similarly, a leading text on criminal interrogations advises police to pose as friends of the suspects, to suggest that confessions will make the suspects feel better or restore their sense of honor or result in lenient punishment, or even to fabricate claims of evidence. ${ }^{61}$ The effort to prevent or punish lies may also

53 Benjamin Constant, On Political Reactions, reprinted in Ecrits et Discours Politiques (O. Pozzo di Borgo ed., 1964) (1797). But cf., Immanuel Kant, 8 Practical Philosophy 427 (Mary Gregor ed. \& trans. Cambridge Univ. Press, 1996).

54 Henry Sidgwick, The Methods of Ethics 316 ( $7^{\text {th }}$ ed. 1981/1907).

55 Trey Popp, House Dentist, 115 Penn. Gazette 34, 37-38 (May/June, 2017).

56 Valeriya Safronova, Two Etiquette Experts Take on New York, N.Y. Times, Style sec., May 28, 2017.

57 Zahra Nader \& Mujib Mashal, In Afghanistan, Women Struggle After a Divorce, N.Y. Times, April 18, 2017.

58 John Stuart Mill, On Liberty 89 (Gertrude Himmelfarb ed., Harmondsworth: Penguin, 1974) (1859).

59 Id. at 76.

60 Alan K. Chen \& Justin Marceau, High Value Lies, Ugly Truths, and the First Amendment, 69 VAND. L. Rev. 1435, 1438 (2015).

61 FredE.Inbau,JohnReid, JosephP.Buckley, \&BryanC.JAyne, Criminal Interrogation ANd Confessions ( $5^{\text {th }}$ ed. 2011). But cf., Miriam Gohara, A Liefor a Lie: False Confessions and the Case for Reconsidering the Legality of Deceptive Interrogation Techniques, 33 Fordham Urb. L. J. 791, 793 (2006); Patrick McMullen, Questioning the Questions: The 
discourage people from speaking on controversial topics from a fear of possible prosecution, and thus impede the discovery of truth. By the same token, a parody consisting of deliberate falsehoods does not generate tort liability, as this might bring about a chilling effect that might hinder the pursuit of truth. ${ }^{62}$

Thus, if a rationale for denying speech the protection of the first amendment is that it be "of such slight social value as a step to truth that any benefit that may be derived from [it] is clearly outweighed by the social interest in order and morality," ${ }^{\prime 3}$ then some lies will win favor and others will not. "A good man does not lie," wrote a prominent legal philosopher, and yet "many lies do little if any harm, and some lies do real good." ${ }^{64}$ The assumption that lies necessarily lack the social value that would warrant first amendment protection, in sum, is simplistic and misplaced.

What, then, makes an honest person? Is it simply someone who does not lie? Since nearly everyone lies at least occasionally, this would seem to make the honest person a kind of moral unicorn, who exists only in the imagination. Most people, who excuse lying under a number of circumstances, would likely find this too harsh. For them, an honest person might perhaps be one who does not lie with malicious intent. (There might, of course, be degrees of honesty, reflecting how often or how seriously, one violates the norm.) But some would insist that honesty is incompatible with lying, whatever its purpose. In this sense, the virtue of honesty in real life might sometimes seem too harmful to be virtuous. The alternative, however, would be to confuse honesty with something else, perhaps compassion.

A few words on liars. Why do they lie? The standard answer is that they believe the anticipated benefits exceed the anticipated costs. ${ }^{65}$ But what are the benefits? If I make a false claim about the Yugo I am trying to sell you, the benefit is obvious: the money I acquire from your buying my defective old car. But lies may also call on less tangible motives; the presentation of self is often misleading in order to manage the impressions we give to others, enhancing other people's opinion of us and avoiding social awkwardness and embarrassment. ${ }^{66}$ Incentives to lie are seemingly everywhere.

Impermissibility of Police Deception in Interrogations of Juveniles, 99 Nw. Rev. L. Rev. 971, 975 (2005).

62 Hustler Magazine, Inc. v. Falwell, 485 U.S. 46, 52-55 (1988).

63 Chaplinsky v. New Hampshire, 315 U.S. 568, at 572 (1942). The Supreme Court examined the harmless lie in oral arguments preceding its decision in Maslenjak v. United States. The government sought to revoke the citizenship of a naturalized citizen for making an immaterial statement in her naturalization application, which requires applicants to note any criminal offense, regardless of how trivial and regardless of whether they were arrested; Chief Justice Roberts asked if he could be deported for not revealing that he had once driven five miles an hour over the speed limit, Justice Sotomayor would have refused to disclose an embarrassing childhood nickname, and Justice Kagan wondered whether she could have been expelled for lying about her weight; to derisive laughter, the government's assistant solicitor general answered, Yes. Matt Ford, Will the Supreme Court Defend Naturalized Citizenship? The AtLantic, May 2, 2017.

64 Charles Fried, Right and Wrong 54 (1978).

65 Gordon Tullock, Toward a Mathematics of Politics (1967); Michael L. Davis \& Michael Ferrantino, Toward a Positive Theory of Political Rhetoric: Why Do Politicians Lie? 88 Public Choice 1 (1996).

66 Erving Goffman, The Presentation of Self in Everyday Life (1956). 


\section{United States v. Alvarez}

Xavier Alvarez, a minor official on a local water board, announced at a public meeting, "I'm a retired Marine of twenty-five years. I retired in the year 2001. Back in 1987, I was awarded the Congressional Medal of Honor. I got wounded many times by the same guy." ${ }^{\prime 67}$ All of these statements were lies. Alvarez was charged with violating the Stolen Valor Act, which made it a crime to lie about receiving military medals. ${ }^{68}$ He pleaded guilty, reserving the right to challenge the law's constitutionality, and was ordered to pay a $\$ 5,000$ fine. He appealed, charging that his right to free speech under the first amendment was abridged.

The Court of Appeals for the Ninth Circuit upheld his claim. Judge Milan D. Smith, speaking for the court, feared that if the law were sustained, "there would be no constitutional bar to criminalizing lying about one's height, weight, age, or financial status on Match.com or Facebook, or falsely representing to one's mother that one does not smoke, drink alcoholic beverages, is a virgin, or has not exceeded the speed limit while driving on the freeway." 69 Thus would government have "license to interfere significantly with our private and public conversations." 70 Judge Smith conceded that Alvarez's lie did not promote the marketplace of ideas, but added that this could be said about most lies, with the result that government prosecution would be intrusive and "inconsistent with the maintenance of a robust and uninhibited marketplace of ideas." " For "the right to speak and write whatever one chooses - including, to some degree . . . demonstrable untruths - without cowering in fear of a powerful; government is . . . an essential component of the protection afforded by the First Amendment." 72 Later, Smith invoked the famous clear and present danger test, concluding that the law failed the test. ${ }^{73}$ Nor was he persuaded that the law was the "best and only way to ensure the integrity of [military] medals," ${ }^{74}$ speculating that the damage from lying would fall on the liars rather than the awards system. In the end, Smith was skeptical of permitting "the government to police the line between truth and falsity."75 Judge J. S. Bybee, dissenting, believed that precedents had established that lies are not protected unless "protection is necessary "to protect speech that matters," "'76 a condition that clearly did not apply here.

The government appealed the ruling to the Supreme Court, but the result was the same. Justice Anthony Kennedy, writing for a plurality, acknowledged that

${ }_{67}$ United States v. Alvarez, 132 S. Ct. 2537, 2542. Alvarez might profitably have studied the life of Enric Marco, who became famous in Spain as spokesman for the Spanish survivors of Nazi concentration camps, producing endless books, articles, and speeches, in effect transforming himself into a suffering hero celebrated by generations. JAVIER Cercas, The Imposter: A True Story (Frank Wynne trans., 2018).

6818 U.S.C. sec. 704 (2005).

69617 F. 3d 1198, $1200(2010)$.

$70 \quad$ Id. at 1204.

${ }_{71}$ Id.

$72 \quad I d$. at 1205.

$73 \quad I d$.at 1215.

$74 \quad I d$.at 1217.

$75 \quad I d$ at 1218.

$76 \quad I d$. at 1231. 
honoring military heroism was a legitimate governmental purpose, but considered the law a content based restriction, which meant that it must be examined with strict scrutiny, that is, it must serve a compelling government interest and it must be narrowly tailored. ${ }^{77}$ There may be a compelling interest in preserving the integrity of the medals, but the law's language, Kennedy found, was so sweeping that it endorsed the principle that government could punish any false statements, and this would have a chilling, self censoring effect on speech. ${ }^{78}$ Nor did the government show a direct link between the goal of the law and its operation; ${ }^{79}$ there was no evidence presented that lies undermined public trust in the awards or that counter speech, perhaps facilitated by a government created data base, ${ }^{80}$ would not be adequate to combat lies. ${ }^{81}$ "The remedy for speech that is false is speech that is true," ${ }^{82}$ Kennedy wrote, not Orwell's Ministry of Truth. ${ }^{83}$ The law, in sum, was clearly insufficiently narrow. That the lies were of no apparent social value and, in fact, were alleged to have caused harm did not disqualify them from protection.

Justice Stephen Breyer, concurring, thought Alvarez's lies did not call for the high level of scrutiny that Kennedy demanded, for the lies did not advance valuable ideas and were easily verifiable. ${ }^{84}$ Still, he was troubled by the sweeping character of the law that could invite prosecutorial abuse ${ }^{85}$ and by the failure of the government to explain why a more narrowly tailored approach would not work. ${ }^{86}$ He favored an intermediate level of protection, something between the tough strict scrutiny and the soft rational basis tests. ${ }^{87}$

Justice Samuel Alito, dissenting, concluded that the law was sufficiently narrow, as it covered only factual lies within the speaker's personal knowledge, and because the lies had no value, prosecuting them would not chill valuable speech. ${ }^{88} \mathrm{He}$ chided the majority for acting counter to many precedents and other laws that punish lies that serve no legitimate interest. Instead, he compared the law to trademarking, where it is understood that the proliferation of cheap imitations of luxury goods dilutes the brand; he thought it was reasonable for Congress to conclude that the same result would occur with military honors.$^{89}$ For if Alvarez's type of lie, Alito showed, were common, a steady stream of exposés would feed public skepticism about the awards system. A comprehensive database would be of little help, he explained, because records went back only to $2001^{90}$.

Although the justices each exude a potent confidence, it is clear that they had not entirely subdued the congeries of slippery problems. Kennedy, for example,

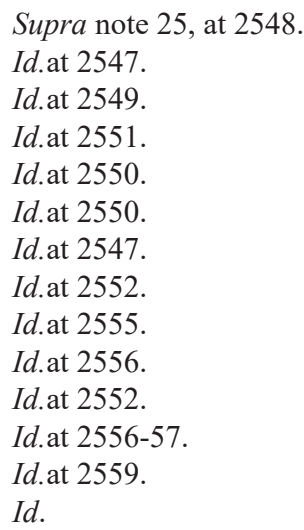


differentiates between harm causing and non-harm causing lies. But what kind or magnitude of harm would satisfy him? The government's concern about the devaluation of military awards seemed sufficiently harmful to Congress, but did not convince him. Is this the kind of question that requires a judicial answer or should it be left to the judgment of the legislature? And is it really plausible that lawmakers would extend the principle to criminalize all lies or is this the kind of hobgoblin Emerson saw fluttering around petty consistencies? ${ }^{91}$ Certainly, it is hard to see how punishing lying about winning a combat medal could justify punishing lying about one's virginity, where a legitimate government interest is nearly impossible to discern. Breyer, for his part, seems to be suggesting that some lies are valuable - perhaps lies from investigative reporters that might help in the pursuit of truths and others - perhaps like Alvarez's - are not. Again, the perennial problem of line drawing presents itself.

Of course, it is obvious that we lie everyday for a variety of purposes, good and bad, and that whole industries (for example, cosmetics, plastic surgery, veneer paneling, food dyes, toupees) exist to deceive. Punishing lying per se would revolutionize human relations, denying the social functions that lying plainly performs; it has not become ubiquitous by random chance. Alito insists that the issue is not punishing all lying, but simply lying about military medals. But is his rationale self limiting? And who would draw the limits, the elected and democratically accountable Congress or the appointed and independent courts? Where Kennedy emphasizes the value of individual expression and believes tolerating lies demonstrates the strength of society, Alito sees a societal value in celebrating military heroism and worries that tolerating lies will invite disrespect. The marketplace that Kennedy would trust to solve the problem seems to Alito sadly inadequate.

Alvarez also speaks to the relation of truth to authenticity. In common speech, the terms are sometimes treated interchangeably, but the case suggests that they overlap and nothing more. For if authenticity means be-who-you-are, Alvarez was, quite simply, a pathological liar. His lies in this case, as Judge Smith observed, "were only the latest in a long string of fabrications. Apparently, Alvarez makes a hobby of lying about himself," including tales about a second Medal of Honor won for rescuing the American ambassador to Iran during the hostage crisis, playing hockey for a professional team, working as a policeman, and secretly marrying a Mexican movie starlet. Perhaps Alvarez imagines that his pursuit of happiness entitles him to construct his own fantasy persona, but this entirely ignores its effect on other people.

\section{Susan B. Anthony List v. Driehaus}

In political campaigns (as in war), truth is often the first casualty. Yet even in this age of fake news, it is obvious that beyond a certain point, campaign lies generate toxic effects: they undermine voter efforts to hold officials accountable; they generate cynicism and its progeny, alienation and apathy; they lower the tone of campaigning, discouraging high minded persons from participating; and they

91 Ralph Waldo Emerson, Self-Reliance, in Essays And English Traits, 63,70 (C.W. Eliot ed. 1909). 
encourage unethical persons to run for office, increasing the likelihood of official malfeasance and corruption. Efforts to punish campaign lies, in sum, are not short of justifications. Yet though no one defends such lies, the issue, again, is not simple. Susan B. Anthony List v. Driehaus (2016) involved an Ohio law that prohibited lying in campaign materials during campaigns in order to promote the election, nomination, or defeat of a candidate. ${ }^{92}$ Susan B. Anthony List, a pro-life organization, had tried to purchase a billboard sign reading, "Shame on [Congressman] Steve Driehaus! Driehaus voted FOR taxpayer funded abortion." In fact, Driehaus had voted for the law in question only after receiving assurances from the President that taxpayer funding would not fund abortions. Driehaus warned the advertising company involved in purchasing the billboard sign about a possible suit, and it refused the ad, but he nonetheless filed a complaint with the state board of elections, claiming that Susan B. Anthony List had knowingly and falsely accused him of voting for taxpayer funded abortions. After he lost the election, he withdrew his complaint, but Susan B. Anthony List maintained that as long as the law remained, the organization would be subject to a chilling effect from fear of possible future suits. At the time, at least eighteen states had similar laws. ${ }^{93}$

A federal district court handed down a permanent injunction that prevented Ohio from enforcing the law, and Susan B. Anthony List took the case to the Court of Appeals for the Sixth Circuit. There, Chief Judge R. Guy Cole announced that it was bound by Alvarez, and must apply the strict scrutiny standard. ${ }^{94}$ Ohio had a compelling interest in preserving the integrity of its elections, he acknowledged, but because the law was content based and targeted political speech, which lies at the core of first amendment protections, it also had to be narrowly tailored. In this, the law failed. Complaints were often useless because they were not concluded before the election or in time for a candidate to recover from the false charges; the complaint process could be abused to tar an opponent or divert resources; there was no procedure for eliminating frivolous complaints. ${ }^{95}$ Behind his arguments, Judge Cole seemed to be pointing to the commonplace that lies and falsehoods are not exactly unknown in campaigns, that the system has always relied on the marketplace to make final judgments, and that, consequently, the first amendment denies government a determining role. Though he did not address it, there was also the matter of the advertising company being deterred from accepting the ad from the same lawsuit threat. Unaddressed (because it was not germane to the facts of the case) was false speech designed to reduce voter turnout, for example, by providing inaccurate information on the place and time of voting or eligibility rules. ${ }^{96}$

The commonplace that campaigns often feature lies suggests that lying might best be evaluated by examining prevailing norms in particular contexts. Machiavelli ${ }^{97}$ and

92 Ohio Rev. Code Ann. Sec. 3517.21 (B) (2013).

93 Margaret Zhang, Susan B. Anthony List v. Driehaus and the (Bleak) Future of Statutes that Ban False Statements in Political Campaigns, 164 U. PA. L. Rev. 19 (2015).

94 Susan B. Anthony List v. Driehaus, 814 F. 3d 466, 472 (2016).

95 Id. at 474-76.

96 Staci Lieffring, Note, First Amendment and the Right to Lie; Regulating Knowingly False Campaign Speech After United States v. Alvarez, 97 Minn. L. Rev. 1047, 1078 (2013).

97 Niccolo Machiavelli, The Prince (1950). He famously advised leaders to learn "how not to be good" (p. 57). 
Weber ${ }^{98}$ maintained, for example, that leaders' social responsibilities exempted them from the claims of ordinary ethical responsibilities as they performed their public duties. Thus, in safeguarding the polity, Machiavelli's prince might be called upon to lie and deceive. ${ }^{99}$ Similarly, firms may engage in puffery (so long as they adhere to the law) in their pursuit of profits; ${ }^{100}$ lawyers may try to mislead juries in the hope of seeking an acquittal of a client they believe to be guilty; would-be buyers and sellers may pretend that certain dollar figures represent their final offers; and card players may bluff as to the cards they hold. Within reasonable limits, these lies may be tolerated as following established norms, ${ }^{101}$ in the sense that audiences should expect them; if we suspect that we will be deceived, we will greet the lies suspiciously, and so it will be harder for us to be taken in. Put differently, if we try to excuse our lying by pointing out that everyone lies, we also undermine our credibility. Susan B. Anthony List could offer this defense; Alvarez could not. Still, the lesson from Alvarez and Susan B. Anthony List would seem to be that the first amendment may in certain circumstances protect lies, both trivial and significant, leaving them to the marketplace to sort out.

\section{NATIONAL INSTITUTE OF FAMILY AND LIFEAdVOCATES V. BECERRA}

The National Institute of Family and Life Advocates (NIFLA) case focuses not on outright lies, but instead on arguably deceptive omissions. NIFLA operates hundreds of non-profit crisis pregnancy centers (CPCs), which offer services to pregnant women and try to persuade them not to have abortions. ${ }^{102}$ California's Reproductive FACT Act required CPCs to post the following notice: "California has public programs that provide immediate free or low-cost access to comprehensive family planning services (including all FDA-approved methods of contraception), prenatal care, and abortion for eligible women." The notice also informed clients as to whether the CPCs were licensed as medical facilities. ${ }^{103}$ If they were not licensed, they were banned from performing medical procedures. Failure to comply risked a fine of $\$ 500$ for the first offense and $\$ 1000$ for subsequent offenses. NIFLA, which operates $111 \mathrm{CPCs}$ in California, sought a preliminary injunction on the ground that the statute abridged its first amendment rights to free speech and the free exercise of religion. The district court denied the motion, ${ }^{104}$ concluding that NIFLA had not demonstrated that it would likely prevail on the merits, a necessary precondition for such an injunction. ${ }^{105}$ NIFLA appealed to the Ninth Circuit.

98 Max Weber, Politics as a Vocation, in From Max Weber 77-128. (Hans H. Gerth \& C. Wright Mills trans. \& ed. New York: Oxford Univ. Pr., 1946)

99 Supra note 97, ch. 18. See Michael Walzer, The Problem of Dirty Hands, 2 PHIL. \& PuB. AFFs. 160 (1973).

100 Albert Z. Carr, Is Business Bluffing Ethical? 46 Harv. Bus. Rev. 143 (1968).

101 That is, "shared understandings about actions that are obligatory, permitted, or forbidden." Elinor Ostrom, Collective Action and the Evolution of Social Norms, $14 \mathrm{~J}$. ECo. Perspectives 137, 143-44 (2000).

102 Nationwide, there are between 2,000-4,000 CPCs, substantially more than the number of abortion providers.

103 Cal. Health \& Safety Code, secs. 123472(a)(2)(A)-(C) and (a)(10-(2).

104 Civil No. 15c2277 JAH(DHB) (Sept. 29, 2017).

105 Winter v. Natural Resources Defense Council, 555 U.S. 7, 22 (2008). 
After conceding that the case was sufficiently ripe and that NIFLA had standing to sue, the court addressed the merits of the case. In a detailed forty page opinion, Judge Dorothy W. Nelson methodically dealt with NIFLA's complaints. The act is content based, she admitted, and this ordinarily triggers strict scrutiny. But this test is unwarranted in this case for two reasons: first, because courts have recognized "a state's right to regulate physician's speech concerning abortion" 106 and to regulate the medical profession generally; ${ }^{107}$ and second, because the act does not discriminate on the basis of viewpoint, in the sense that it targets a particular opinion, point of view or ideology. ${ }^{108}$

Nor, she held, did the licensing notice requirement require strict scrutiny because regulating speech between a professional and a client calls to mind "speech in the context of medical treatment, counseling or advertising," and professional speech merits only intermediate scrutiny. ${ }^{109}$ Can California show that the act directly advances a substantial governmental interest and is drawn to meet that interest? Yes, because "California has a substantial interest in the health of its citizens," 110 and the notice "is closely drawn [in] fully informing Californians of the existence of publicly-funded medical services." 111 Nor was there a problem with the unlicensed notice, for the act simply requires a one sentence statement informing women that the facility had not met state licensing standards; the state has a compelling interest, and the law is narrowly tailored. ${ }^{12}$ Nor did the act unconstitutionally interfere with the free exercise of religion because it was neutral with general application. ${ }^{113}$ Thus, NIFLA had not met the burden of demonstrating a likelihood to succeed on the merits. The district court's decision was upheld. ${ }^{114}$

Though Judge Nelson alluded to "the Legislature's findings regarding the existence of CPCs, which often present misleading information to women about reproductive medical services," ${ }^{115}$ she delicately danced around the state's central

106 National Institute of Family and Life Advocates v. Harris, D.C. No. 3:15-cv-02277-JAHDHB, 22. Kamala Harris had replaced Xavier Becerra as attorney general of California.

107 Id. at 23.

108 Id. at $19-20$.

$109 \quad I d$ at. 30.

$110 \quad I d$. at 32.

111 Id. at 33.

112 Id. at 33-35.

113 Id. at 38.

114 In Greater Baltimore Center for Pregnancy Concerns \& St. Brigid's Roman Catholic Congregation v. Baltimore, the Fourth Circuit decided a similar case differently. A Baltimore ordinance required CPCs to post signs in their waiting rooms that they did not offer or refer patients for abortions; the Greater Baltimore Center refused to do so, though it included this message in a pamphlet available in their waiting room. The court denied that the ordinance covered commercial or professional speech, viewing the ordinance as compelling the CPC to "portray abortion as one among a menu of morally equivalent choices. . . . [a] message . . . antithetical to the very moral, religious, and ideological reasons the Center exists." No. 16-2325, 15 (2018). As Baltimore over seven years could not identify a single woman who was misled and as the ordinance did not require abortion centers to post a pro-life message, it amounted to "[w]eaponizing the means of government against ideological foes" (p. 20), which violates the first amendment.

115 Supra note 106, at 35. 
complaint: that CPCs employ "intentionally deceptive advertising and counseling practices [that] often confuse and intimidate women from making fully-informed, time-sensitive decisions about critical health care." 116 More aggressively, a congressional investigation had reached the same conclusion a decade earlier; twenty-three federally funded CPCs were contacted, and twenty of them provided false or misleading information on the health consequences of abortion. ${ }^{117}$ The staff may wear lab coats like doctors but not be doctors; the clinics may be named so as to imply that they perform abortions, but their purpose is to discourage women from having abortions, sometimes by offering misinformation. ${ }^{118}$

Some deceptions, of course, are harmless or even beneficial, but the court found it hard to imagine that NIFLA's deception fell into these categories, for plainly some women who might otherwise have chosen abortion will claim to have been harmed by NIFLA's deception that turned them away from this option (just as some who ignored NIFLA's deception will say they were harmed by abortions). But even if, arguendo, NIFLA harmed no one, there is still the Kantian matter as to whether the deceptive means are justified by the end.

The Ninth Circuit did not persuade the Supreme Court. Justice Clarence Thomas, speaking for a five member majority, found the law defective. Content based regulations of speech must pass the strict scrutiny test, he observed, but forcing NIFLA to inform women about abortions "plainly 'alters the content' of petitioners speech." 119 Yet the lower circuit did not apply the test, tagging the notice as professional speech that is subject to regulation. But Thomas denied that the Court had previously recognized such a category, though "precedents have applied more deferential review to some laws that require professionals to disclose factual, noncontroversial information." 120 Abortion, however, is "anything but an "uncontroversial' topic." 2121 He conceded that an earlier Court had upheld a law requiring a state to provide certain information to a woman as a condition of obtaining her consent to an abortion, but justified this as facilitating "informed consent to a medical procedure"; in the NIFLA case, however, "it is not tied to a [medical] procedure at all." 122 Regulation of so-called professional speech, moreover, would interfere with the operation of the marketplace of ideas.

Thomas also found the law to be "wildly underinclusive," 123 in the sense that it applied only to a minority of community clinics, chiefly affecting the speech of pro-life clinics disagreeing with the state. This implied that the purpose of the law was less to inform women than to disfavor the pro-life point of view. In any event, there exist many means to inform women of their abortion rights without forcing these clinics to do so. California, he wrote, "imposes a government-scripted,

116 Hearing on A.B. 75 before Senate Committee on Health, 2015-2016 session 6 (Cal. 2015), ECF No. 11-6, 6.

117 House of Representatives, Committee on Government Reform, False and Misleading Health Information Provided by Federally Funded Pregnancy Resource Centers (July 2006).

118 Of course, evidence of an effort to deceive does not establish that deception took place.

119138 S.Ct. 2361, 585 U.S. _(2018).

120 Id.

121 Id.

$122 I d$.

123 Id. 
speaker-based disclosure requirement that is wholly disconnected from the state's informational interest." 124 Thomas was dubious that pregnant women needed to be informed as to "when they are getting medical care from licensed professionals," 125 for California had offered no empirical evidence in support of this proposition. At one point, Thomas implicitly compared the California statute to policies pursued by Nazi Germany, Mao's Cultural Revolution, and Ceausescu's Romania. ${ }^{126}$

In a brief concurrence, Justice Kennedy addressed the first amendment issue more directly. He saw the law as "a paradigmatic example of the serious threat presented when government seeks to impose its own message in the place of individual speech, thought, and expression." 127 Where California had lauded the statute as "part of California's legacy of "forward thinking," Kennedy retorted that it "is forward thinking to begin by reading the First Amendment as ratified in 1791." 128 As a lawyer defending the center put it, "the government loses its power to force pro-life pregnancy centers to provide free advertising for abortion." 129

Justice Breyer, writing for the four dissenters, took a characteristically practical approach. "Virtually every disclosure law could be considered "content based," he said, "for virtually every disclosure law requires individuals to speak a particular message. ... [T] he majority's approach at the least threatens considerable litigation over the constitutional validity of much, perhaps most, government regulation."130 The reference to the marketplace of ideas he also found far fetched. If a state may "insist that medical providers tell women about the possibility of adoption [it] should also allow states similarly to insist that medical providers tell women about the possibility of abortion." 131 And "carrying a child to term and giving birth," he wrote, is no less a medical procedure than abortion. ${ }^{132}$ As to the complaint that California had not demonstrated that women need to be informed as to whether they are receiving care from licensed practitioners, he thought it was "self-evident."133

Clearly, it was California's transparent lack of neutrality that drove NIFLA's arguments. NIFLA observed that the statute was admittedly aimed at pro-life pregnancy centers, forcing them to supply information on obtaining abortions. It did not compel abortion clinics to post signs informing women about the prolife alternative. Accordingly, NIFLA argued, the law came up against the maxim: "freedom of speech prohibits the government from telling people what to say." 134 The right to speak, from this perspective, implies a right not to speak that should be applied even handedly: if pro-choice clinics are not required to provide anti-

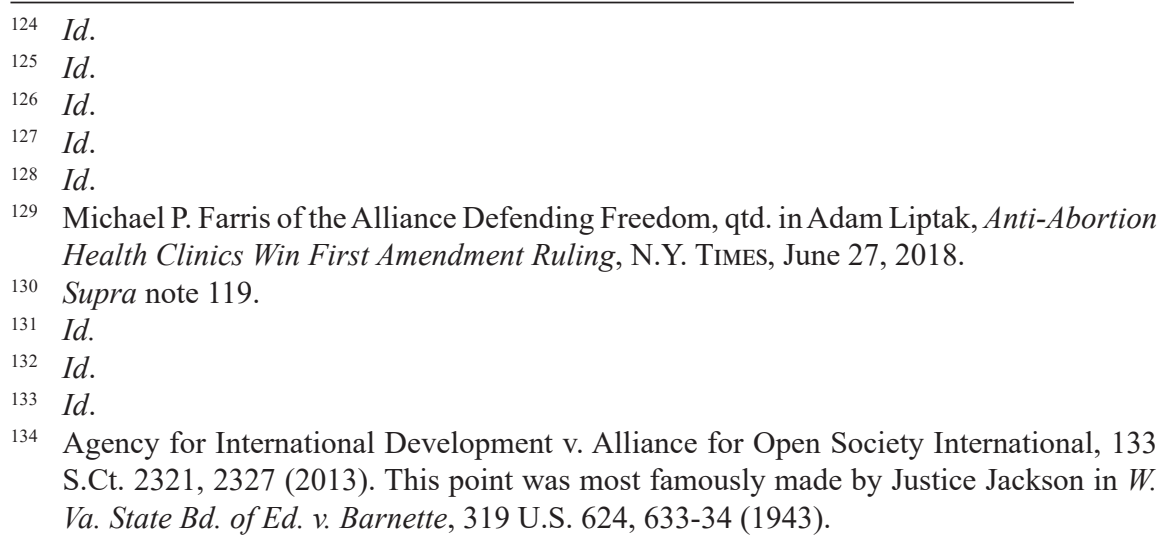


abortion information, pro-life clinics should not be required to provide abortion information. The state cannot avoid its responsibility to be neutral by pretending that the required statement is merely informational, for it is information that supports a particular policy position.

But the problem, according to California, was that NIFLA was not simply a pro-life clinic. It was a pro-life clinic masquerading as a clinic with no ideology. Requiring NIFLA to post the abortion information notice would not unmask them as liars, but it might make their deception harder to pull off. In this sense, the case resembles a decision upholding a congressional requirement that campaign donors disclose their names. ${ }^{135}$ Admittedly, as Mill argued, there is value in confronting truth with falsehoods as a means of saving truth from degenerating into "dead dogma, not a living truth." 136 Yet Thomas' reference to the marketplace of ideas notwithstanding, the point of NIFLA's refusal to post the abortion clinic information was to avoid confrontation and impede the discovery of truth. In the course of doing so, it contravened the general principle that health providers inform patients of treatment options, so they can make informed decisions. Where the majority was speaker-centric, the minority was listener-centric. ${ }^{137}$ The clinic objects to being forced to advance a practice it finds abhorrent; the women are denied important information from a fear that they will choose the wrong lawful option.

Must a state, in any event, be neutral as to abortion? California plainly was not neutral. It was clearly in the pro-life camp. At oral argument, Justice Alito asked, "Isn't it possible to infer intentional discrimination?"138 California replied that the law also affected a "significant" body of pro-choice clinics, as well, but, perhaps fearful of provoking further controversy, claimed that the law was intended merely to inform pregnant women, not to prevent them from being deceived. The result, however, was to provoke Justice Gorsuch to demand to know why it was the task of the "limited number of clinics ... to provide that information." He was clearly troubled that California was attempting "to force a private speaker to do that for you under the First Amendment." 139

On the other hand, some states are plainly in the pro-life camp. For example, eighteen states require that abortion providers inform women that abortion increases the risk of breast cancer or mental illness or suicide or that pre-viable fetuses feel pain, though none of these claims are accurate. ${ }^{140}$ And in the important Planned Parenthood of Southeastern Pennsylvania v. Casey (1992), the Supreme Court upheld a pro-life statute that mandated physicians to provide "printed materials" to women "describing the fetus and providing information about medical assistance for childbirth," plus "information about child support from the father" and "a list of agencies which provide adoption and other services as alternatives to abortion. ${ }^{141}$

What this illustrates is that states take policy positions all the time, preferring one goal to another or one means to another. Indeed, that is what governing is. One

135 Buckley v. Valeo, 421 U.S. 1 (1976).

136 Supra note 58, 97.

137 Martin H. Redish \& Peter B. Siegel, Constitutional Adjudication, Free Expression, and the Fashionable Art of Corporation Bashing, 91 Tex. L. Rev. 1425, 1469 (2013).

138 Supreme Court Oral Argument, Nat'l Institute of Family \& Life Assocs. v. Becerra (Heritage Reptg., Mar. 20, 2018) at 38.

139 Id. at 42.

140 Id. at 46.

141505 U.S. 833. 
is reminded of Holmes' famous dissent in Lochner, when he scolded the majority for claiming that that in labor-management questions, the state must be hands-off neutral. The Constitution, he said, did not "enact Mr. Herbert Spencer's Social Statics." 142 It did not, that is, require laissez faire policies but on the contrary was "made for people of fundamentally different views." 143 The majority, acting as if the law were a series of abstract propositions that could decide cases by deduction, misunderstood the very nature of law, which represents the political forces within societies and was always in flux, favoring first one side and then another.

But that California may take a pro-choice position in NIFLA still leaves open the question as to whether it can force private parties to do the same. California maintained that the act did not require clinics to endorse abortion or recommend it to their clients or say anything it does not believe. Yet the obvious purpose of the informational statement on abortion availability was to facilitate abortions. It was not merely a stray bit of information, like the capitol of Paraguay, that one might find in an almanac, but a borderline advertisement for the practice. However, if government can require that McDonald's post the calories in its Big Macs and Marlboros the dangers of smoking, it is odd that NIFLA escaped. The Court has held that legislative restrictions on commercial speech bear a "heavy burden" in advancing a state interest. ${ }^{144}$ But the majority was not convinced. In this sense, the case reflects the Court's troubles in dealing with compelled speech. In one case where fundraisers were required to disclose the percentage of contributions that actually went to the charity, the Court saw this as content based and struck down the law. ${ }^{145}$ In another case, however, the Court upheld a requirement that universities be compelled to circulate information on military recruiters, even where the universities did not want the military on their campuses. ${ }^{146}$

Can the government, then, "promote any message it deems desirable"? ${ }^{147}$ The obvious answer is: no. The government, for example, cannot reinstate "white" and "colored" rest room signs, as this would violate the equal protection clause. But short of such constitutional issues, the government is, indeed, free to promote any message, with the understanding that a free political process involving public opinion, parties, the media, interest groups, and so on, will operate to challenge it. When writers raise the hypothetical that "there is no binding practical restraint that prevents the Postal Service"148 from printing Adolf Hitler's face on postage stamps, they ignore the potent popular opposition that render such a decision unthinkable. Indeed, government speech may contribute to the democratic process by provoking such controversies. ${ }^{149}$ As Justice Alito put it in a different case, "the

142 Lochner v. New York, 198 U.S. 45, 75 (1905).

$43 \quad I d$. at 76.

144 Sorrell v. IMS Health, 564 U.S. 552 (2011); 44 Liquormart v. Rhode Island, 517 U.S. 484 (1996).

145 Riley v. Nat'l Fed. of the Blind, 487 U.S. 781 (1988).

146 Rumsfeld v. FAIR, 547 U.S. 47 (2006).

147 Ilya Shapiro, Trevor Burrus, \& Meggan Dewitt, Not Everything Professionals Say Is "Professional Speech," Cato at Liberty, Dec. 26, 2017, 01.58 PM, https://www.cato.org/ blog/not-everything-professionals-say-professional-speech.

148 Daniel J. Hemel \& Lisa Larrimore Ouellette, Public Perceptions of Government Speech 2018 Sup. Ct. Rev. 33, 54. (2018).

149 Keller v. State Bar of California, 496 U.S. 1, 10-11 (1990). 
government is not required to maintain viewpoint neutrality in its own speech." ${ }^{150}$ Should government anti-littering signs require government pro-littering signs? ${ }^{151}$ On the other hand, nothing in the statute forbade the centers from adding signs that sought to refute the message in the required signs. For example, next to the abortion notification might be placed a photograph of an aborted fetus.

On the other hand, if the public does not understand that the message comes from the government - perhaps, it utilizes private doctors to carry its message $\mathrm{e}^{152}$-it may not be able to hold officials accountable, and the fact that some government directives raise no problems, does not mean that no such directives raise problems. ${ }^{153}$ There is a consensus that smoking is dangerous and Hitler was evil, but as Thomas noted, there is hardly a consensus on the morality of abortion. ${ }^{154}$ A consensus, moreover may change as new facts become known - it was long falsely believed that stomach ulcers were caused by stress - and a past consensus - like the white population's belief in the inferiority of non-whites - may crumble as social values evolve. Truth and morality cannot finally be determined by majority rule.

Requiring a statement on licensing, however, appears easy to justify. If the act required an unlicensed person performing ultrasounds to say that he or she was unlicensed, why object? Isn't the purpose similar to deterring firms from committing fraud with deceptive or misleading advertising? Does the reasonableness of protecting the consumer/client disappear merely because no financial profit is sought? A barber must display his license. Is it too much to ask a clinic to inform its clients as to its license? When NIFLA prevailed and CPC licensing requirements were disregarded, Breyer wondered whether any licensing law could be enforced..$^{155}$

\section{Ronald H. Coase, “Advertising ANd Free SpeEch”}

Years earlier, Ronald Coase, later a Nobel laureate in economics, argued for extending first amendment protection to advertising. If consumers can choose freely in the marketplace of political and social ideas, he asked, why not in the marketplace of ideas about goods and services? If government "is regarded as

$150 \quad$ Matal v. Tam, 137 S. Ct. 1744, 1747 (2017).

151 Because NIFLA so obviously concerns government speech, it is unnecessary here to inquire as to the nature and limits of non-governmental speech. See, e.g., Pleasant Grove v. Summum, 55 U.S. 460 (2009) (privately donated religious monument in a public park); Walker v. Texas Division, Sons of Confederate Veterans, 135 S. Ct. 2239 (2015) (privately designed automobile license plate). These cases also highlight the difficulty the public may have in distinguishing public from private speech.

152 Rust v. Sullivan, 500 U.S. 173 (1991).

153 For instance, North Carolina offered pro-life but not pro-choice license plates, and a court held that license plates "amount to government speech and that North Carolina is free to reject license plate designs that convey messages with which it disagrees." 815 F.3d 183 (4 $4^{\text {th }}$ Cir. 2016).

154 Jonathan Kelley, M.D.R. Evans \& Bruce Headey, Moral Reasoning and the Politics of Conflict: The Abortion Controversy, 44 BR. J. Socio. 589 (1993); Michael J. Sandel, Moral Argument and Liberal Toleration: Abortion and Homosexuality, 77 CAL. L. Rev. 539 (1989).

155138 S.Ct. 2361, 2380 (2018) (Breyer, J., dissenting). 
incompetent and untrustworthy in the one market," why consider it "efficient and reliable in the other?"156 It will not do to claim that political and social ideas are more important and deserve more protection because "the great mass of people"157 would disagree; the poet may inveigh against "getting and spending," 158 but most of us give them a higher priority than public policy issues, and if we truly believe in the democratic sovereignty of the people, we can hardly ignore their preference for the mundane simply because we find it inconvenient or banal.

But even if we agreed that political and social ideas were in some cosmic sense more important, it would be irrelevant, for a first amendment that protects nude dancing ${ }^{159}$ and videos of dog fights ${ }^{160}$ is obviously not confined to major things. Some might argue, in fact, that the greater importance of political and social ideas itself justifies heavier regulation; if we falsely are persuaded that a shampoo will make our hair prettier, we can soon test the claim and at worst may have to put up with a few bad hair days. But if we are falsely persuaded that certain groups are inherently evil and in some important sense not fully human, the result might be the Holocaust.

Advertising, in any event, Coase believes is "clearly part of the market for ideas," as it "may provide information or may change people's tastes." ${ }^{161}$ Even if the advertising itself contains no information, if it induces people to consume a product, the act of consumption conveys information. Intellectuals are in the ideas business, and so they naturally value the marketplace of political and social ideas more than goods; they write books and articles, and naturally value their work product higher than the work product of advertisers and have tried to convert the larger society to this point of view. But is an academic essay, say, on Felix Frankfurter, ${ }^{162}$ more socially impactful than an advertisement for beer? The answer is not obvious, and the self importance of intellectuals does not close the case. Indeed, a closer look reveals that publishers, writers, and public speakers are themselves also commercial actors, profiting from their words; only the hermit or the saint does not seek some gain from what he says. Which raises the question of how to distinguish advertising from other speech. The conventional definition of commercial speech is "speech that proposes a commercial transaction," 163 but taken seriously, this capacious definition is hungry for expansion. If a lawyer gives a speech with the thought that it may raise his profile and gain him clients, is this advertising? If an academic presents a paper at a conference in the hope that it might help him get a better position elsewhere, is this advertising? If a salesman befriends a guest at a cocktail party, imagining him a future customer, is this advertising? Moreover, nearly every product conceivably is related to the marketplace of ideas. Advertising for potato chips raises the question as to what we should eat; advertising for video games alerts us as to how we should spend our time.

To regulate or not to regulate? Regulations, whether of ideas or goods, Coase

156 Ronald H. Coase, Advertising and Free Speech, 6 J. Leg. St. 1, 2 (1977).

157 Id. at 4.

158 William Wordsworth, The World Is Too Much With Us.

159 Barnes v. Glen Theatre, 501 U.S. 560 (1991).

160 United States v. Stevens, 559 U.S. 460 (2010).

161 Supra note 156 , at $8,9$.

162 Thomas Halper, Felix Frankfurter and the Law, 7 BR. J. Am. Leg. Studies 115 (2018).

163 Bd. of Trustees, SUNY v. Fox, 492 U.S. 469, 482 (1989). 
reminds us, are designed to benefit those who advance them, typically by narrowing competition. Thus, whether particular regulations are justified can be determined only by examining individual cases. In general, though, for Coase the marketplace, not government, would be relied upon to counter lies and reduce their influence. Yet if courts have become more sensitive to the claims of commercial speech, they show no signs of granting it the level of protection Coase envisions. ${ }^{164}$

\section{CONCLUSIONS}

In the last analysis, we must choose from imperfect, maybe unsatisfactory alternatives. We cannot rely always on markets because we are flawed. We are insufficiently rational and respond emotionally to claims, perhaps because of childhood experiences, rendering us vulnerable to manipulation. Or we are excessively rational and refuse to make the investment necessary to inform ourselves because we recognize that it is simply not worth it. Moreover, faith in the market is not evidence. "Certitude," as Holmes said, "is not the test of certainty."165 On the other hand, it would be naïve to trust the state to identify truth for us, for institutionally and individually in terms of persons acting on its behalf, it has its own interests to protect and advance, and cannot pretend to objectivity or neutrality. Holmes thought the Framers of the first amendment chose the market, and believed that courts should follow this grand experiment. Perhaps it, like Churchill's democracy, can only earn the back handed defense that it is the worst system, except for every other that has been tried from time to time. ${ }^{166}$

164 Coase, supra note 1.

165 Oliver W. Holmes, Natural Law, 32 HaRv. L. Rev. 40, 41 (1918).

166 Cf., House of Commons speech, Nov. 11, 1947; 444 Parl, Deb. HC ( $5^{\text {th }}$ ser.)(1947), col. 203 (UKL). 